\title{
Analysis of contemporary entrepreneurship education system based on interactive and practical teaching methods
}

\author{
Wei Wang ${ }^{1}$, Ying Liu ${ }^{2}$ \\ ${ }^{1}$ Wenzhou Business College School of Information Engineering Wenzhou City. China \\ ${ }^{2} Z$ hejiang Oriental Vocational Technical College Wenzhou City. China
}

Keywords: Interactive, practical teaching method, entrepreneurship education, system analysis.

\begin{abstract}
With the promotion and development of open education, the teaching concept of interactive program teaching method has been one of the topics of great concern to the educational circle. In the past few years, various higher vocational college practical experience indicates that the application of interactive teaching program in higher vocational chemistry teaching process, which can not only stimulate students to learn chemistry passion, can improve the efficiency of college students learning chemistry. Starting from the concept of educational reform and analyzing the application of interactive program teaching method in higher vocational chemistry teaching, it can not only meet the educational requirements of teaching, but also become an innovative teaching idea in the field of education in the future. With the rapid development of economy, the social competition is becoming more and fiercer. Moreover, the enrollment expansion of universities is increasing. College students are facing severe employment pressure. In view of this, entrepreneurship education has become the focus of modern education in major universities. Undergraduate entrepreneurship education has become an important measure in the educational reform of universities and colleges, and it is also a new requirement for the development of modern higher education.
\end{abstract}

\section{Introduction}

Entrepreneurship education by the United Nations called education "third passport", in order to enhance students' entrepreneurial spirit, entrepreneurial awareness and entrepreneurial ability training objectives, as important as the occupation education and academic education, is a new requirement of the development of modern education and education reform and new trends. Facing the rapid development of information technology and knowledge economy, innovation and entrepreneurship have become the theme of the times. This paper explores the entrepreneurship education system of science and engineering undergraduates with high efficiency, and then provides a new way of thinking for undergraduate education in the future.

It is an important content of teaching reform in colleges and universities to adopt interactive teaching model and organize and design the teaching process scientifically and rationally. This kind of teaching model is centered on students, and teachers are transformed from learners of knowledge and learners into learners. The whole teaching process is bidirectional and interactive,. The roles of teachers and students are interchangeable. Under the guidance of the teacher, students acquire knowledge through self-study, and then strengthen the learning effect through teaching. In this way, it not only plays the leading role of the teacher, but also embodies the main role of the students, and arouses the initiative and enthusiasm of the two aspects of teachers and students, so as to achieve good teaching results.

Most of the traditional teaching methods are step-by-step, students do not have much enthusiasm, little space for promotion, there is the separation of knowledge and practice shortcomings. Interactive teaching and modern teaching, make up the traditional teaching sense of the shortcomings, let the classroom become vivid, improve the enthusiasm of students, allow students to learn more knowledge rich and colorful, and improve the students' ability of independent innovation and independent learning, to create a relaxed atmosphere for students to camp. To change the traditional sense of "telling" mode, it helps students to develop brain thinking. The equal exchange and discussion between teachers and students is the main factor to realize the principles of teaching and teaching. 
The interactive teaching method from the modern education concept, to meet the needs of students to study knowledge and talents in social skills and market economy, improve the teachers' level of education and teaching, teaching and learning through the full range of mutual promotion and communication to achieve the objective process called interactive teaching method. The interactive teaching method mainly emphasizes the interaction and communication between students and between teachers and students, focusing on the cultivation of students' comprehensive ability.

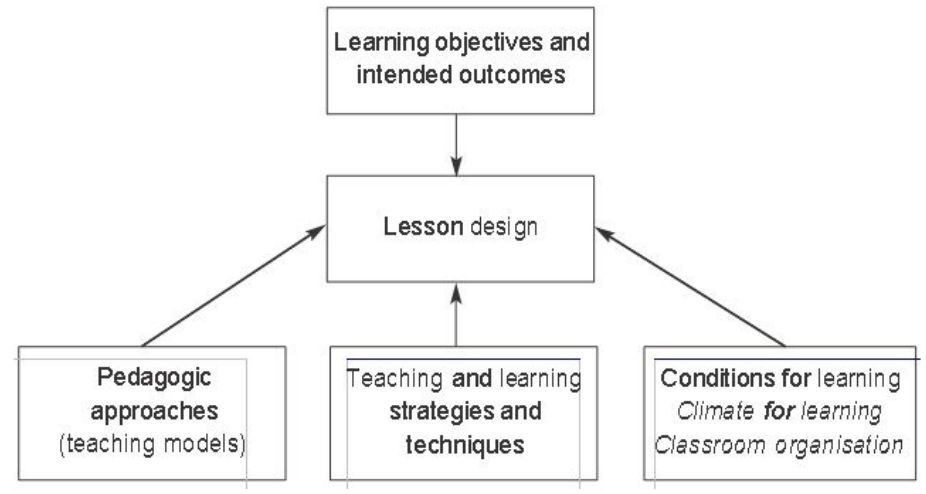

Figure.1 Interactive teaching

\section{The Proposed Methodology}

\subsection{The Significance of Entrepreneurship Education.}

College enrollment in recent years, the whole society is facing increasingly severe employment situation, especially in our country for many years in science and technology boom, the universities of science and engineering undergraduate set to rise sharply, society can provide jobs simply can not meet the needs of graduates, college students employment has become a social problem. The traditional way of higher education is difficult to effectively solve today's severe employment problem. Therefore, it is urgent for colleges and universities to change the traditional educational concepts and methods, reform the training mode of talent education, and cultivate innovative and pioneering students for the society.

Innovation is the source of social progress and development, and an inexhaustible motive force to promote the progress of the country and the nation. The essence of the national competition is the talent competition, economic integration and rapid development in the globalization era, the country wants to be in a favorable position in world competition, rapid changes in the world to better respond to the challenges and different countries, the innovation ability is an important factor. Therefore, the University of Talent Training Base should begin with entrepreneurship education at the strategic level, and cultivate a modern, innovative and entrepreneurial talent with innovative spirit and entrepreneurial ability. Undergraduates of science and engineering majors are active in thinking, creative and innovative, strong in practice and good at integrating professional knowledge into skills practice. To achieve efficient smooth transformation of scientific achievements, industrialization and promoting the development of science and technology, not only to create more social value for society, conveying a large number of innovative talents for social development, promote the construction of innovative country, the social economy is more effective and rapid growth.

Entrepreneurship education originated in the United States is a brand-new education idea and conform to the trend of social development, but in China's recognition of entrepreneurship education and the investment is not enough, only a few key universities pays more attention to the development of entrepreneurship education, and began to take shape. With the corresponding results, polytechnic colleges throughout most of the entrepreneurial education to the degree of attention and enthusiasm is still not high, undergraduate entrepreneurship awareness, entrepreneurship is not strong, the neglect of high-tech knowledge of undergraduate entrepreneurship development, not fully aware of the importance of entrepreneurship education in colleges and universities in the future development of the role played by. For entrepreneurship education in colleges and universities, while government departments also pay more attention to it, but some universities has not formed a system of education 
is not clear, the higher strategic position, not take effective action, resulting in undergraduate entrepreneurship education not only did not receive system, misunderstanding still thought on the isolated and one-sided understanding seriously dampened the enthusiasm and initiative of undergraduate entrepreneurship. Therefore, the backward concept of entrepreneurship and the weak sense of entrepreneurship education have become an important reason for hindering the development of efficient entrepreneurship education.

\subsection{Interactive Teaching Method.}

The choice of teaching methods has never been a uniform standard. The task of a teacher is to make the most flexible use of various teaching methods and select the most suitable one. Generally speaking, the following factors can be taken into consideration in the selection of teaching methods: learning goals, students' needs and personality, students' abilities, students' numbers, and students' motives.

Case law is the best choice to instill knowledge as the goal, be carefully selected case to explain, organize students to participate in the discussion, analysis of problems and proposed solutions, it can fully improve the students' ability of thinking and solving problems. In addition, the game method can also increase students' understanding of what they have learned.

Role play and situational simulation are effective options for changing attitudes. In the course of teaching labor relations disputes, the author designed several scenarios for labor disputes, which enabled students to act as employees, representatives of trade unions and management respectively in negotiations to resolve conflicts. Students through the real scene simulation experience, exercise the ability to deal with complex affairs, learned to transposition thinking.

The model method is an effective way to teach skills. In order to train the students' communication skills, the use of advanced teaching equipment, such as multimedia, projector, selecting and playing about communication misunderstanding and daily etiquette teaching video, and with illustrations and self-demonstration, let the students to distinguish the various body language information transfer. In addition, the author also organizes the student to carry on the speech contest in the classroom, to make their own judgment, if conditions allow, can also use video equipment, the real record of the students, they provide a mirror for students to examine.

\subsection{Selection Strategy Based on Students' Needs and Personality.}

First of all, different teaching methods represent the degree of teacher control or student participation. Teachers need to know the degree of participation of students in different teaching methods, and then choose according to the needs of students.

For example, when talking about the time management section, if taught according to the teaching method, the teacher is a speaker, the student participation is not high. However, if the teacher speak before, let students each day to record their activities, and to spend in each activity on time are analyzed, and suggestions on how to improve your time management skills, then the teacher group discussion, summed up some rules. Finally, on the basis of student discussion, the teacher introduces the theories and methods of time management experts, and allows students to compare their own rules with those of experts, encouraging students to challenge authority. In this way, students can not only connect the knowledge in class with their daily life, but also actively participate in the teaching activities through discussion, debate and so on. In addition, the teaching of specialized English teaching methods can more students to participate in the consideration, such as the relevant professional organization of the controversial English debate and tell the personal views of the speech contest.

In addition to taking into account the learning objectives, students' needs and personality, teachers should also consider the students' ability to accept the teaching methods. For example, the author takes phased teaching in the teaching of specialized English. In addition to the teaching of specialized knowledge, the first stage is supplemented by basic training in listening and speaking skills in English. With the increase of students' professional vocabulary, the transition to the second stage focuses on the training of reading and translation skills. Also in the initial stage of bilingual teaching, using Chinese teaching, appropriate infiltration of English teaching mode, which uses English writing on the blackboard, concept, definition and description of the problem in English teaching, the key and 
difficult to explain with Chinese. After a period of training, students' language and professional abilities have been enhanced, and then the transition to the Chinese and English teaching mode, so that students' professional knowledge in the English environment has been further improved.

\subsection{The Principles of Interactive Teaching Method.}

We should adhere to the principle of development. The task of history classroom teaching lies in everything. For the development of students, all in order to develop students, the development is not only the purpose of education, but also the content of education. In the classroom teaching, teachers should carry out through exploration, discovery, discussion, experiment, games and other activities, the use of heuristic teaching methods, problems and situation and discussions, the students and the learning objects interact with each other, which makes the active cognition, take the initiative to create, get full development.

In traditional teaching, students learn passively, dull atmosphere in the classroom, and in the interactive classroom teaching teachers should respect students' subject status, to create a good educational environment for students and education conditions, development space for students to active, lively, free and inspire the creativity of students, enhance students' subject consciousness, development the subject ability of the students, cultivate students' personality, so as to promote the development of students' subjectivity.

We should adhere to the guiding principle. We emphasize the dominant position of students, does not rule out the dominant position of teachers, that is to say the students play the main role does not mean that the classroom teaching activities of teachers should be in a timely manner to let things drift, guide and control the whole class, found that students in creative speech to be commended, the error is corrected, inspire and guide.

\section{Conclusion}

Compared with the traditional teaching method, interactive teaching method endows many new connotations. It takes more into account the students' personal needs and goals, and takes students as the center to organize the teaching so as to make the students' creative thinking develop effectively. However, the interactive teaching method also has some shortcomings and limitations, play to ignore the teachers in the teaching activities of the leading role of law and practice and learning outcomes in summary, lead to deviations from the teaching objectives and reach the expected teaching effect. Therefore, it is necessary for teachers to adopt flexible and diverse methods in teaching and constantly sum up and perfect them.

\section{References}

[1]. Piperopoulos, Panagiotis, and Dimo Dimov. "Burst bubbles or build steam? Entrepreneurship education, entrepreneurial self - efficacy, and entrepreneurial intentions.”Journal of Small Business Management 53.4 (2015): 970-985.

[2]. Rideout, Elaine C., and Denis O. Gray. "Does entrepreneurship education really work? A review and methodological critique of the empirical literature on the effects of university - based entrepreneurship education.”Journal of Small Business Management 51.3 (2013): 329-351.

[3]. Sánchez, José C. "The impact of an entrepreneurship education program on entrepreneurial competencies and intention." Journal of Small Business Management 51.3 (2013): 447-465. 